\title{
Halálozásikockázat-becslő pontrendszerek alkalmazhatóságának elózetes vizsgálata újraélesztett betegek körében
}

\author{
Kiss Boldizsár dr. ${ }^{1}$ - Fekete-Győr Alexandra dr. ${ }^{2}$ - Szakál-Tóth Zsófia dr. ${ }^{1}$ \\ Párkányi Anna dr. ${ }^{1}$ - Jenei Zsigmond $d r .{ }^{3}$ - Nyéki Péter dr. ${ }^{1}$ \\ Becker Dávid dr. ${ }^{1}$ - Molnár Levente dr. ${ }^{1}$ - Ruzsa Zoltán dr. ${ }^{1}$ - Dér Gábor dr. ${ }^{1}$ \\ Kovács Enikő dr. ${ }^{4}$. Pilecky Dávid dr. ${ }^{5}$. Gellér László dr. ${ }^{1}$ \\ Veli-Pekka Harjola dr. ${ }^{6}$ - Merkely Béla dr. ${ }^{1}$ - Zima Endre dr. ${ }^{1}$
${ }^{1}$ Semmelweis Egyetem, Általános Orvostudományi Kar, Városmajori Szív- és Érgyógyászati Klinika, Budapest
${ }^{2}$ St. George's University Hospital, London \\ ${ }^{3}$ Semmelweis Egyetem, Általános Orvostudományi Kar, Belgyógyászati és Hematológiai Klinika, Budapest \\ ${ }^{4}$ Semmelweis Egyetem, Általános Orvostudományi Kar, Aneszteziológiai és Intenzív Terápiás Klinika, Budapest \\ ${ }^{5}$ Klinikum Passau, Passau \\ ${ }^{6}$ Helsinki University Central Hospital, Department of Emergency Medicine, Helsinki
}

Bevezetés: A cardiovascularis halálokok közül világszerte nagy jelentőségű a hirtelen szívhalál. Annak ellenére, hogy a cardiopulmonalis resuscitatio és a postresuscitatiós intenzív osztályos kezelés is komoly metodikai és technikai fejlödésen ment keresztül az elmúlt időszakban, kevés az olyan validált pontrendszer, amely jól becsülné a beteg intenzív osztályra kerülésekor a mortalitási rizikót.

Célkitüzés: A sikeres újraélesztést követő intenzív osztályos kezelés kezdetekor felmért, a cardiogen shock rizikóstratifikációjára alkalmazott CardShock Risk Score (CSRS) és az általunk hozzáadott, specifikus súlyozófaktorokkal (iniciális ritmus, inotropigény) módosított CardShock Risk Score (mCSRS) összevetése a mortalitás előrejelzésében post-cardiac arrest szindrómás betegeknél.

Módszerek: Retrospektív vizsgálatunk során 172, kórházon kívül sikeresen újraélesztett és klinikánkon ellátott consecutiv betegből a CSRS- és mCSRS-pontrendszerek segítségével végül 123 beteg adatait elemeztük. A CSRS- és mCSRS-változók és a korai/késői mortalitás közötti összefüggést Cox-regressziós analízissel vizsgáltuk. A pontszámok alapján 3 csoportba $(1-3,4-6,7+)$ soroltuk a betegeket. Az összevont csoportok túlélését log-rank teszttel hasonlítottuk össze.

Eredmények: A betegpopuláció átlagéletkora 63,6 év volt (69\% férfi), és a hirtelen szívhalál hátterében 80\%-ban akut coronaria szindróma állt. A korai/késői mortalitást leginkább a felvétel utáni neurológiai állapot, a szérumlaktátszint, a vesefunkció, az iniciális ritmus és a beteg katecholaminigénye határozta meg. A mCSRS alkalmazását követően mind az „1-3” és a „4-6” ( $\mathrm{p} \leq 0,001)$, mind a „4-6” és a „7+” ( $\mathrm{p}=0,006)$ csoportok között szignifikáns különbséget találtunk a túlélésben.

Következtetés: A felvételkori pontok alapján a mCSRS pontosabban definiálja és differenciálja egymástól az általunk beválasztott két extra súlyozófaktorral az enyhe, a közepes és a magas mortalitási rizikóval bíró betegpopulációkat, mint a CSRS.

Orv Hetil. 2021; 162(2): 52-60.

Kulcsszavak: újraélesztés, postresuscitatiós ellátás, mortalitás, rizikó

\section{Pilot analysis of the usefulness of mortality risk score systems at resuscitated patients}

Introduction: Sudden cardiac death is one of the most significant cardiovascular causes of death worldwide. Although there have been immense methodological and technical advances in the field of cardiopulmonary resuscitation and following intensive care in the last decade, currently there are only a few validated risk-stratification scoring systems 
for the quick and reliable estimation of the mortality risk of these patients at the time of admission to the intensive care unit.

Objective: Our aim was to correlate the mortality prediction risk points calculated by CardShock Risk Score (CSRS) and modified $(\mathrm{m})$ CSRS based on the admission data of the post-cardiac arrest syndrome (PCAS) patients.

Methods: The medical records of 172 out-of-hospital resuscitated cardiac arrest patients, who were admitted at the Heart and Vascular Centre of Semmelweis University, were screened retrospectively. Out of the 172 selected patients, 123 were eligible for inclusion to calculate CSRS and mCSRS. Based on CSRS score, we generated three different groups of patients, with scores 1 to 3,4 to 6 , and 7+, respectively. Mortality data of the groups were compared by log-rank test.

Results: Mean age of the patients was 63.6 years (69\% male), the cause of sudden cardiac death was acut coronary syndrome in $80 \%$ of the cases. The early and late mortality was predicted by neurological status, serum lactate level, renal function, initial rhythm, and the need of catecholamines. Using mCSRS, a significant survival difference was proven in between the groups " $1-3$ " vs " $4-6$ " ( $\mathrm{p} \leq 0.001)$, “4-6" vs " $7+$ " ( $\mathrm{p}=0.006)$.

Conclusion: Compared to the CSRS, the mCSRS expanded with the 2 additional weighting points differentiates more specifically the low-moderate and high survival groups in the PCAS patient population treated in our institute.

Keywords: resuscitation, post-resuscitation care, mortality, risk

Kiss B, Fekete-Győr A, Szakál-Tóth Zs, Párkányi A, Jenei Zs, Nyéki P, Becker D, Molnár L, Ruzsa Z, Dér G, Kovács E, Pilecky D, Gellér L, Veli-Pekka H, Merkely B, Zima E. [Pilot analysis of the usefulness of mortality risk score systems at resuscitated patients]. Orv Hetil. 2021; 162(2): 52-60.

(Beérkezett: 2020. június 1.; elfogadva: 2020. július 24.)

\section{Rövidítések}

$\mathrm{AED}=$ (automated external defibrillator) félautomata defibrillátor; $\mathrm{APACHE}=($ acute physiology and chronic health evaluation) az akut fiziológiai és krónikus egészségi állapot értékelése; $\mathrm{BKEF}=$ bal kamrai ejekciós frakció; $\mathrm{BLS}=$ (basic life support) alapszintú újraélesztés; CABG = coronariaartéria-bypassgraft; $\mathrm{CAD}=($ coronary artery disease $)$ coronariaartériabetegség; CKD-EPI = (Chronic Kidney Disease Epidemiology Collaboration) krónikus vesebetegség-epidemiológiai együttmúködés; CRP $=$ C-reaktív protein; CSRS $=($ CardShock Risk Score) cardiogen shock kockázati pontszám; eGFR = (estimated glomerular filtration rate) becsült glomerulusfiltrációs ráta; ERC $=($ European Resuscitation Cuncil $)$ Európai Újraélesztési Tanács; ESICM = (European Society of Intensive Care Medicine) Európai Intenzív Terápiás Társaság; EuReCa $=(\mathrm{Eu}-$ ropean Registry of Cardiac Arrest) Európai Szívmegállás Regiszter; IHCA = (in-hospital cardiac arrrest) kórházon belüli szívmegállás; mCSRS $=$ (modified CardShock Risk Score) módosított cardiogen shock kockázati pontszám; NEAK = Nemzeti Egészségbiztosítási Alapkezelő; OHCA = (out-of-hospital cardiac arrest) kórházon kívüli szívmegállás; OMSZ = Országos Mentôszolgálat; PCAS $=$ (post-cardiac arrest syndrome) szívmegállás utáni szindróma; $\mathrm{PEA}=$ (pulseless electrical activity) pulzus nélküli elektromos aktivitás; ROSC = (return of spontaneous circulation) a spontán keringés visszatérése; SAPS $=($ simplified acute physiology score $)$ egyszerúsített akut élettani pontszám

A hirtelen szívhalált úgy definiáljuk, mint egy cardialis okú természetes halált, amely esetében a halálhoz vezető tünetegyüttes első tüneteinek fellépése és a végső klinikai esemény (hirtelen szívmegállás) között maximum egy óra telik el $[1,2]$. A hirtelen szívmegállások két fó csoportba oszthatók: kórházon belüli (IHCA) - és kórhá- zon kívüli (OHCA) szívmegállás. A felosztást a különböző etiológiai tényezők aránya, a különböző ellátási szintek és azok prognózisbeli különbsége indokolja. A hirtelen szívhalál jelentőségét mutatja, hogy a világszerte hozzávetőlegesen évi 17 millió, cardiovascularis ok miatt bekövetkező halálozás $25 \%$-a hirtelen szívhalál [3]. A hirtelen szívhalál felelős az összes haláleset közel 15\%-áért az Amerikai Egyesült Államokban és más, iparilag fejlett országokban $[1,2,4,5]$. Annak ellenére, hogy a cardiopulmonalis resuscitatio, az intenzív osztályos utókezelés és a rehabilitáció terén komoly metodikai és technikai fejlődések történtek, még mindig komoly mortalitással bír a hirtelen szívhalál. Megállapítható, hogy a korábban említett fejlődések következtében az újraélesztés túlélése szignifikánsan nőtt a korábbi évekhez képest [6].

A OHCA incidenciája igen széles tartományban mozog (38-150/100 000 eset/év) a különbözó közlések szerint $[5,7,8]$. Ezen tartomány függ a földrajzi és a demográfiai tényezőktől, illetve nem utolsósorban az adatforrástól is. A hirtelen szívhalál incidenciáját a nem és az életkor is meghatározza. Férfiakban magasabb, mint nőkben $(\widehat{\partial}:$ ㅇ $=60: 40)$, ez a különbség azonban a 60. és a 80. életév között kiegyenlítődik. Az életkor elórehaladtával a hirtelen szívhalál incidenciája növekszik $[1,9]$.

Magyarországon 2003 óta van összegyújtött epidemiológiai adat a OHCA-ra vonatkozóan. A Göbl és mtsai által előadás formájában közölt adatok szerint 30 hónap alatt 13767 , kórházon kívüli szívmegállást regisztráltak, ami 55/100 000 eset/év incidenciát jelent $[10,11]$. A későbbi EuReCa ONE tanulmány keretében közölt, részleges adatok szerint a magyarországi incidencia 
1. táblázat |A hirtelen szívhalál etiológia szerinti csoportosítása [4]

\begin{tabular}{|c|c|c|c|}
\hline \multicolumn{3}{|c|}{ Cardiovascularis } & \multirow[t]{3}{*}{ Nem cardiovascularis } \\
\hline \multicolumn{2}{|c|}{ Strukturális } & \multirow[t]{2}{*}{ Nem strukturális } & \\
\hline Ischaemiás & Nem ischaemiás & & \\
\hline $\begin{array}{l}\text { - Coronariabetegség infarctussal } \\
\text { vagy anginával } \\
\text { - Coronariaembolisatio } \\
\text { - Nem atherogen CAD (arteritis, } \\
\text { dissectio, veleszületett } \\
\text { coronariaanomália) } \\
\text { - Coronariaspasmus }\end{array}$ & $\begin{array}{l}\text { - Hypertrophiás CM } \\
\text { - Dilatativ CM } \\
\text { - Billentyúbetegségek } \\
\text { - Veleszületett - szívbetegség } \\
\text { - ARVC } \\
\text { - Myocarditis } \\
\text { - Akut pericardialis tamponád } \\
\text { - Akut myocardialis ruptura } \\
\text { - Aortadissectio }\end{array}$ & $\begin{array}{l}\text { - Idiopathiás VF } \\
\text { - Brugada-szindróma } \\
\text { - LQTS } \\
\text { - Preexcitációs szindróma } \\
\text { - Komplett blokk } \\
\text { - Familiáris hirtelen szívhalál } \\
\text { - Mellkasfali trauma } \\
\text { - Shock }\end{array}$ & $\begin{array}{l}\text { - Pulmonalis embolia } \\
\text { - Koponyaûri vérzés } \\
\text { - Fulladás } \\
\text { - Pickwick-szindróma } \\
\text { - Drog } \\
\text { - Centrális légúti obstrukció } \\
\text { - SIDS } \\
\text { - SUDEP }\end{array}$ \\
\hline
\end{tabular}

ARVC = arrhythmogen jobb kamrai cardiomyopathia; CAD = coronariaartéria-betegség; CM = cardiomyopathia; LQTS = hosszú-QT-szindróma; SIDS = hirtelen csecsemőhalál szindróma; SUDEP = hirtelen váratlan halál epilepsziában; VF = kamrafibrilláció

azonban kétszeres értéket (118/100 000 eset/év) mutatott [8].

A keringésmegállás közvetlen oka leggyakrabban egy hirtelen kialakuló szívritmuszavar (arrhythmia). Ezen malignus szívritmuszavarok lehetnek az újraélesztés ellátása alatt sokkolandó (kamrai tachycardia, kamrafibrilláció) és nem sokkolandó (pulzus nélküli elektromos aktivitás [PEA], bradycardia, asystolia) ritmusok $[1,4]$.

A hirtelen szívhalál etiológiája változatos. A fó okokat csoportosíthatjuk eredet szerint: strukturális, nem strukturális cardiovascularis betegségek és nem cardiovascularis betegségek [4]. A hirtelen szívhalál etiológiája szerinti csoportosítása az 1. táblázatban látható részletezve.

A hirtelen szívhalál hátterében számos - etiológiájából logikusan adódó - rizikófaktor áll, úgymint az életkor, a nem, a genetika, az angina, korábbi myocardialis infarctus, illetve a coronariaartéria-betegség (CAD) rizikófaktorai (magas vérzsírértékek és vérnyomás, fizikai inaktivitás, dohányzás, cukorbetegség, obesitas, emelkedett CRP, pozitív családi anamnézis CAD-re és myocardialis infarctusra) $[2,4,12]$.

A hirtelen szívhalál áldozatainak megközelítőleg 50\%ában az esemény pillanatában nem volt diagnosztizált szívbetegsége, mégis a legtöbb esetben a fel nem ismert ischaemiás szívbetegség állt a háttérben [13]. A hirtelen szívhalál prevenciója elsősorban a cardiovascularis rizikófaktorok megelózésére és kezelésére terjed ki. Mi több, a preventív stratégiák célja definiálni a megnövekedett hirtelen szívhalál rizikójú, ismert betegséggel bíró csoportokat vagy egyéneket adott tünetmentes populációkban (például versenyszerúen sportolók). A fó szekunder prevenciós célcsoportot a myocardialis infarctust elszenvedett betegek alkotják csökkent bal kamrai ejekciós frakcióval.

A keringésmegállás gyors és szakszerú ellátást igényel, mivel az újraélesztés alatti hosszú hypoperfusio az agy, a szívizom és más vitális célszervek károsodását is okozhatja. Napjainkban a hirtelen szívhalál ellátása az Európai Újraélesztési Tanács (ERC) legfrissebb - 2015-en megjelent - ajánlása szerint történik. Az új ajánlás kiemelt hangsúlyt fektet a laikus által végzett, mentőirányító és AED által segített korai BLS-re (alapszintú újraélesztésre), mely magában foglalja a szívleállás gyors felismerését, a segítséghívást és a minőségi mellkaskompressziót [14].

Az esetlegesen elhúzódó újraélesztés alatt kulcsfontosságú a reverzibilis okok feltárása és adekvát kezelése az újraélesztés sikerének, a spontán keringés visszatérésének érdekében. Ezen reverzibilis okokat az ajánlás egyszerúen, könnyen megjegyezhetően csoportosította $(4 \mathrm{H}$ : hypoxia, hypo-/hyperkalaemia, hypothermia, hypovolaemia; 4T: tenziós pneumothorax, tamponád [szív], thrombosis [embolia, akut coronaria szindróma], toxinok). Az újraélesztés utáni intenzív osztályos ellátás külön fejezetet kapott a 2015-ös ajánlásban, melyben az ERC az Európiai Intenzív Terápiás Társasággal (ESICM) közösen dolgozta ki a protokollt. Ezek felhívják a figyelmünket a postresuscitatiós ellátás jelentőségére [14].

Post-cardiac arrest szindrómáról (PCAS) a spontán keringés visszatérését (ROSC) követően beszélhetünk. A PCAS definíció szerint olyan tünetegyüttes, melynél többszervi ischaemiás-reperfúziós károsodás áll a háttérben újraélesztést követően, ezért az érintett betegek komplex intenzív terápiás ellátásra szorulnak, melynek célja helyreállítani a keringést (értve ezalatt a stabil szívritmust és az adekvát szöveti perfúziót), a megfelelő központi idegrendszeri funkciót és nem utolsósorban az életminőséget [15]. Az újraélesztett beteg rövid és hoszszú távú túlélését is jelentősen befolyásolja a beteg életkora, más ismert vagy eddig lappangó alapbetegségek, az iniciális ritmus, a keringés-összeomlás ideje (a „no-flow” állapot időtartama) és a cardiopulmonalis resuscitatio („low-flow” állapot) időtartama [16]. A postresuscitatiós időszakban alkalmazott kezelés jelentősen meghatározza a végső kimenetelt, különös tekintettel a neurológiai felépülésre $[17,18]$. Ezen intenzív osztályos ellátás része a „targeted temperature management”, azaz a célorientált hőmérséklet-kezelés az optimális neurológiai kimenetel érdekében [19].

Jelenleg kevés olyan validált pontrendszer van, amely jól becsülné a kórházon kívül sikeresen újraélesztett be- 
teg intenzív osztályra kerülésekor a mortalitási rizikót [20]. Jelenleg használunk az intenzív terápiás gyakorlatban mortalitási rizikóbecslésre validált pontrendszereket, mint a SAPS II [21] és az APACHE II [22], de ezek bonyolultak a mortalitási rizikó gyors becslésére, és a felvételt követő első órákban nem áll rendelkezésünkre minden szükséges paraméter.

\section{Módszerek}

Mivel az újraélesztés után a cardiogen shockhoz hasonló, célszervperfúziós zavarral járó „post-no-flow és lowflow” állapot alakul ki, és a hirtelen szívhalál eseteinek túlnyomó része cardiovascularis háttérre vezethető viszsza, a cardiogen shockban alkalmazott CardShock Risk Score-t (CSRS) vettük alapul. A CSRS-t a mortalitás előrejelzésére használta egy skandináv munkacsoport cardiogen shock esetén. A pontérték számításánál figyelembe kell venni a kórházi ellátás kezdetekor a következő paramétereket: az életkort, a bármilyen okú nem intakt tudatállapotot, az előzetes myocardialis infarctust vagy coronariaartéria-bypassgraftot (CABG), az akut coronaria szindróma etiológiát, a csökkent bal kamrai ejekciós frakciót (BKEF), a felvételkori emelkedett szérumlaktátszintet, illetve a felvételkori beszúkült vesefunkciót (eGFR). Utóbbi 2-2 pont lehet. A CSRS-ban egy beteg maximum 9 pontot kaphat. A CSRS-pontrendszer változóinak súlyozását az annak első leírását publikáló tanulmány szerint végeztük [23].

A módosított CSRS-ban (mCSRS) az általunk vélt két, az újraélesztett beteg mortalitását szignifikánsan befolyásoló súlyozótényezôvel egészítettük ki a CSRS-t.

Az egyik súlyozófaktornak (1 súlypont) a beteg újraélesztés utáni katecholaminigényét vettük, hiszen bizonyított tény, hogy a beteg katecholaminigénye súlyosabb cardiovascularis állapotra utal, illetve magasabb mortalitással jár együtt [24]. Egyelőre nem tettünk különbséget az igényelt katecholamin minősége, dózisa, illetve a mono- és kombinált terápiák között a súlypontozással. Munkacsoportunkkal az általunk vizsgált betegpopuláción korábban bizonyítottuk, hogy a kombinált katecholaminigényű betegek esetén egyértelműen alátámasztható a terápia ellenére is fennálló szervperfúziós zavar, mely jól jelzi az állapot súlyosságát [25]. Nagyobb esetszámot feldolgozó publikációk is bizonyítják, hogy míg az újraélesztés alatt adott adrenalin hatására a ROSC esélye jóval magasabb, az 1 hónapos túlélés jelentős csökkenést mutat $[26,27]$. Összegezve, az újraélesztés alatti és utáni gyógyszeres keringéstámogatás igénye súlyosabb, előrehaladottabb cardiovascularis és akár más célszervi eltérésre hívja fel a figyelmet a hirtelen szívhalál hátterében.

A másik, általunk hozzáadott súlyozófaktor ( 1 súlypont) a nem sokkolandó iniciális ritmus (asystolia, perzisztens bradycardia, PEA). Azon szívleállások túlélése, melyekben az iniciális ritmus nem sokkolandó, a túlélés valószínűtlen mindaddig, amíg a - bevezetésben részletezett - reverzibilis okokat $(4 \mathrm{H}-4 \mathrm{~T})$ az újraélesztés köz- ben fel nem fedezzük és adekvátan nem kezeljük [14]. 2014. és 2015. évi publikációk is megerősítik, hogy a nem sokkolandó iniciális ritmus magasabb mortalitást jelez [28-30]. Munkacsoportunk az általunk vizsgált betegpopuláción is megállapította, hogy a hirtelen szívhalált követően lényegesen rosszabb prognózissal rendelkeznek az iniciálisan nem sokkolandó ritmusú betegek: alacsonyabb a sikeres újraélesztés aránya, rosszabb a kimenetel, és több a társbetegség a késóbbiekben [31]. A mCSRS-ban a maximálisan elérhető súlypont 11.

Retrospektív vizsgálatunk során 172 consecutiv, 2008 és 2017 között kórházon kívül sikeresen újraélesztett, majd a Semmelweis Egyetem Városmajori Szív- és Érgyógyászati Klinikájának intenzív osztályain kezelt betegek adatait dolgoztuk fel. A kórházon kívüli szívmegállások közé soroltuk azon eseteket is, melyeknél a kiérkező mentőegység szívmegállás előtti, ún. „periarrest” állapotban találta a beteget, majd a mentőegység jelenlétében történt a szívmegállás és az újraélesztés. Adatforrásul a kórházi elektronikus adatrögzítő rendszer, a kórlapok, a lázlapok és az Országos Mentőszolgálat (OMSZ) jelentólapjai szolgáltak. Kizárólag azon betegek adatait elemeztük $(n=123)$, akiknél az összes, a pontrendszerben használt paraméter a rendelkezésünkre állt (1. ábra).

Mivel az egyes pontértékekhez tartozó elemszámok kevésnek bizonyultak az önálló mortalitáselemzéshez, összevont ( ,0-3”, „4-6” és „7 pont feletti”) csoportokat képeztünk, s azokat vizsgáltuk és hasonlítottuk össze. A betegek túlélését a Nemzeti Egészségbiztosítási Alapkezelő (NEAK) nyilvántartási adatai szerint vizsgáltuk. Az utolsó lekérdezés időpontja: 2020. május 3. A betegek túlélésének utánkövetését 360 napban maximalizáltuk. Az adatok rögzítését és a populáció jellemzőinek egyszerü leíró statisztikai elemzését Microsoft Excel for Mac (version 16.29.1.; Microsoft Corporation, Red-

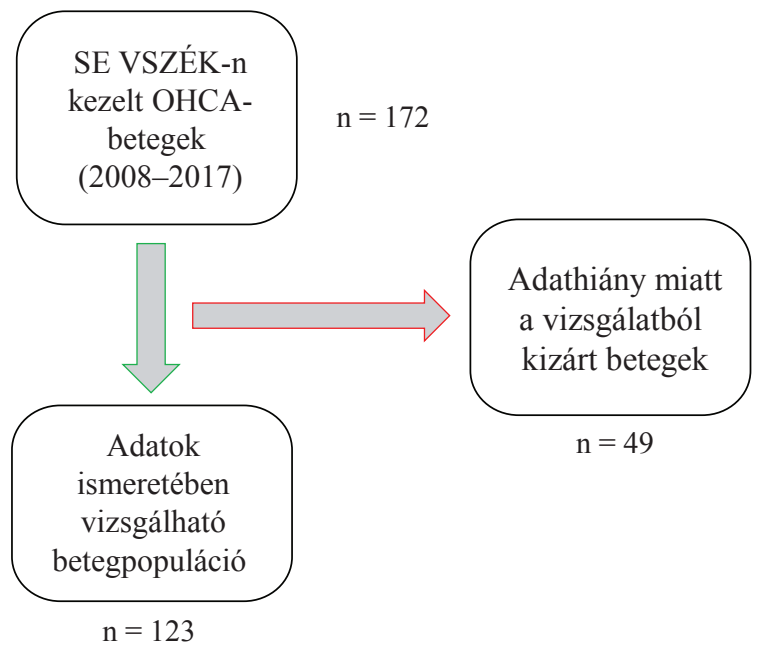

1. ábra $\quad$ A vizsgálatba bevont betegek adatelemzésének folyamatábrája OHCA = kórházon kívüli szívmegállás; $\mathrm{SE}$ = Semmelweis Egye tem; VSZÉK = Városmajori Szív- és Érgyógyászati Klinika 
mond, WA, USA) programmal végeztük. A CSRS- és mCSRS-változók, illetve a 30 és 360 napon belüli mortalitás összefüggésének vizsgálatára, a különböző súlyponttal bíró csoportok közötti összehasonlítására a logrank (Mantel-Cox-) tesztet IBM SPSS 25.0.1 programmal (IBM Corporation, Armonk, New York, NY, USA) végeztük. A folyamatos változók felosztását (úgymint $\mathrm{BKEF}$, szérumlaktátszint és eGFR $\mathrm{CKD}_{\mathrm{EPI}}$ ) mind a validált és közölt CardShock-tanulmányban [23], mind a klinikai vizsgálatokban is nemzetközileg elfogadott és alkalmazott szintek szerint határoztuk meg.

\section{Eredmények}

Az általunk vizsgált, kórházon kívüli szívmegállások helyszín szerinti megoszlása így alakult: közel 50\%-ban a betegek otthonában, 21\%-ban közterületen, 10\%-ban a mentőautóban, 7\%-ban háziorvosi rendelőben, 12\%-ban egyéb helyeken történt az újraélesztés.

2. táblázat |A vizsgált populáció jellemzői

\begin{tabular}{|c|c|}
\hline Esetszám (n) & 123 \\
\hline Átlagéletkor (év \pm SD) & $63,6 \pm 12,1$ \\
\hline \multicolumn{2}{|l|}{ Nem } \\
\hline Férfi, n (\%) & $85(69,1)$ \\
\hline Nö, n (\%) & $38(30,9)$ \\
\hline Myocardialis infarctus (anamnézisben), n (\%) & $30(24,4)$ \\
\hline CABG (anamnézisben), n (\%) & $3(2,4)$ \\
\hline Prehospitálisan adott adrenalin, n (\%) & $75(63,8)$ \\
\hline \multicolumn{2}{|l|}{ Iniciális sokkolandó ritmus } \\
\hline $\mathrm{VF}, \mathrm{n}(\%)$ & $73(59,3)$ \\
\hline VT, n (\%) & $9(7,3)$ \\
\hline \multicolumn{2}{|l|}{ Iniciális nem sokkolandó ritmus } \\
\hline Asystolia, n (\%) & $24(19,5)$ \\
\hline PEA, n (\%) & $12(9,8)$ \\
\hline Bradycardia, n (\%) & $5(4,1)$ \\
\hline Akut coronaria szindróma etiológia, n (\%) & $98(79,7)$ \\
\hline $\mathrm{BKEF}(\% \pm \mathrm{SD})$ & $39,4 \pm 11,9$ \\
\hline Szérumlaktát $(\mathrm{mmol} / \mathrm{l} \pm \mathrm{SD})$ & $4,8 \pm 3,6$ \\
\hline $\mathrm{eGFR}_{\text {CKD-EPI }}\left(\mathrm{ml} / \mathrm{min} / 1,73 \mathrm{~m}^{2} \pm \mathrm{SD}\right)$ & $59,0 \pm 20,7$ \\
\hline Invazív gépi lélegeztetés, n (\%) & $112(91,1)$ \\
\hline \multicolumn{2}{|l|}{ Katecholamin az első 6 órában } \\
\hline Noradrenalin, n (\%) & $41(35,3)$ \\
\hline Dobutamin, n (\%) & $17(13,8)$ \\
\hline Dopamin $(<5 \mu \mathrm{g} / \mathrm{ttkg} /$ perc $), \mathrm{n}(\%)$ & $17(13,8)$ \\
\hline Dopamin (>5 $\mu \mathrm{g} / \mathrm{ttkg} /$ perc $), \mathrm{n}(\%)$ & $8(6,5)$ \\
\hline
\end{tabular}

$\mathrm{BKEF}=$ bal kamrai ejekciós frakció; $\mathrm{CABG}=$ coronariaartéria-bypassgraft; CKD-EPI = krónikus vesebetegség-epidemiológiai együttmúködés; eGFR = becsült glomerulusfiltrációs ráta; $\mathrm{PEA}=$ pulzus nélküli elektromos aktivitás; $\mathrm{SD}=$ standard deviáció; $\mathrm{VF}$ = kamrafibrilláció; VT $=$ kamrai tachycardia
A teljes vizsgált populációra vonatkozó, a CSRS- és a mCSRS-pontrendszerben meghatározott változók jellemzői a 2. táblázatban láthatók. Kiemelendő ezek közül, hogy az átlagéletkor 63 év feletti, a férfiak aránya több mint kétszeres volt, illetve a betegek több mint 90\%-a lélegeztetve volt az újraélesztést követő intenzív terápiás ellátás során a vizsgált populációban. A betegek mintegy negyede szenvedett korábban myocardialis infarctust, illetve a hirtelen szívhalál hátterében közel 80\%ban akut coronaria szindróma állt. Az elsődleges ellátás során észlelt, gyakoribb iniciális ritmus sokkolandó volt, ezek közül is közel 60\%-ban kamrafibrilláció állt a keringés-összeomlás hátterében.

A 3. táblázatban részletezzük a betegcsoport vizsgált változóinak összefüggését a korai (30 nap), illetve a késői (360 nap) mortalitással.

A korai, 30 napon belüli mortalitást kiemelten csökkentette az ellátórendszerbe történő felvételkori intakt neurológiai állapot, a $40 \%$ feletti BKEF, a $4 \mathrm{mmol} / \mathrm{l}$ alatti szérumlaktátszint, a $60 \mathrm{ml} / \mathrm{min} / 1,73 \mathrm{~m}^{2}$ feletti eGFR, az iniciális sokkolandó ritmus, azon belül is a kamrafibrilláció. A korai mortalitást kiemelten növelő változók a $40 \%$ alatti BKEF, a $4 \mathrm{mmol} / 1$ feletti szérumlaktátszint, a $60 \mathrm{ml} / \mathrm{min} / 1,73 \mathrm{~m}^{2}$ feletti eGFR, az iniciális nem sokkolandó ritmus, ezen belül is a pulzus nélküli elektromos aktivitás, illetve a sikeresen újraélesztett beteg intenzív terápiás ellátás alatti katecholaminigényei voltak.

A késői, 360 napon belüli mortalitást kiemelten csökkentette az intakt neurológiai állapot az újraélesztést követően, az akut coronaria szindróma etiológia a hirtelen szívhalál hátterében, a $40 \%$ feletti $\mathrm{BKEF}$, a $4 \mathrm{mmol} / 1$ alatti szérumlaktátszint, a $60 \mathrm{ml} / \mathrm{min} / 1,73 \mathrm{~m}^{2}$ feletti eGFR és az iniciális sokkolandó ritmus, azon belül is a kamrafibrilláció. A késői mortalitást a koraihoz hasonlóan kiemelten növelte a $40 \%$ alatti BKEF, a $4 \mathrm{mmol} / \mathrm{l} \mathrm{fe}-$ letti szérumlaktátszint, a $60 \mathrm{ml} / \mathrm{min} / 1,73 \mathrm{~m}^{2}$ alatti eGFR, az iniciális nem sokkolandó ritmus, ezen belül is a pulzus nélküli elektromos aktivitás és az asystolia, illetve a sikeresen újraélesztett beteg katecholaminigénye az ellátás során.
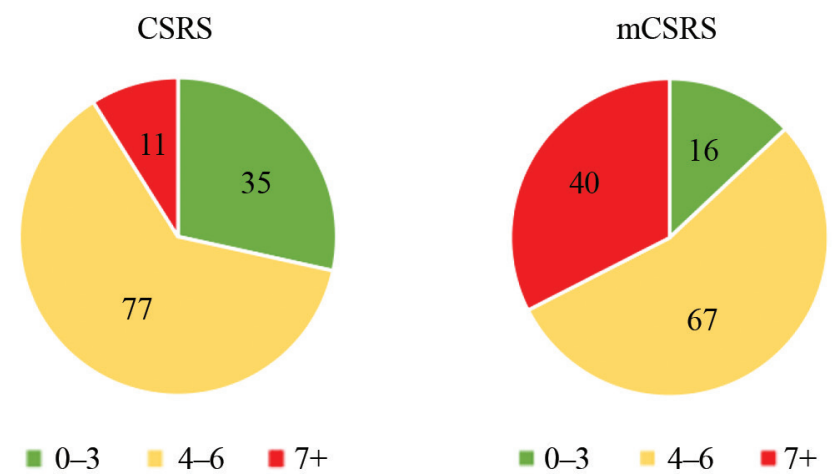

2. ábra A CSRS- és a mCSRS-pontrendszer szerinti összevont csoportok elemszáma

CSRS = cardiogen shock kockázati pontszám, $\mathrm{mCSRS}=$ módosított cardiogen shock kockázati pontszám 
3. táblázat |A CSRS- és mCSRS-változók és a 30, illetve 360 napos mortalitás összefüggése a teljes populációban

\begin{tabular}{|c|c|c|c|c|}
\hline & \multicolumn{2}{|c|}{30 napon belüli mortalitás } & \multicolumn{2}{|c|}{360 napon belüli mortalitás } \\
\hline & OR $(95 \% \mathrm{CI})$ & p-érték & OR $(95 \% \mathrm{CI})$ & p-érték \\
\hline Életkor & - & ns & - & ns \\
\hline Intakt neurológia felvételkor & $0,143(0,020-1,037)$ & 0,054 & $0,272(0,086-0,865)$ & 0,027 \\
\hline Anamnesztikus myocardialis infarctus & - & ns & - & ns \\
\hline Anamnesztikus CABG & - & ns & - & ns \\
\hline Akut coronaria szindróma etiológia & - & ns & $0,508(0,311-0,829)$ & 0,007 \\
\hline \multicolumn{5}{|l|}{ BKEF } \\
\hline$<40 \%$ & $1,769(1,031-3,035)$ & 0,039 & $1,724(1,102-2,697)$ & 0,017 \\
\hline$>40 \%$ & $0,565(0,329-0,970)$ & 0,039 & $0,580(0,371-0,907)$ & 0,017 \\
\hline \multicolumn{5}{|l|}{ Szérumlaktát } \\
\hline$<4 \mathrm{mmol} / \mathrm{l}$ & $0,349(0,198-0,615)$ & $<0,001$ & $0,489(0,312-0,766)$ & 0,002 \\
\hline$>4 \mathrm{mmol} / \mathrm{l}$ & $2,868(1,625-5,059)$ & $<0,001$ & $2,046(1,305-3,209)$ & 0,002 \\
\hline \multicolumn{5}{|l|}{ eGFR ${ }_{\text {CKD-EPI }}$} \\
\hline$<60 \mathrm{ml} / \mathrm{min} / 1,73 \mathrm{~m}^{2}$ & $2,952(1,643-5,304)$ & $<0,001$ & $2,233(1,411-3,533)$ & 0,001 \\
\hline$>60 \mathrm{ml} / \mathrm{min} / 1,73 \mathrm{~m}^{2}$ & $0,339(0,189-0,608)$ & $<0,001$ & $0,448(0,283-0,709)$ & 0,001 \\
\hline Iniciális sokkolandó ritmus & $0,414(0,242-0,708)$ & 0,001 & $0,371(0,236-0,583)$ & $<0,001$ \\
\hline Kamrafibrilláció & $0,475(0,278-0,813)$ & 0,007 & $0,398(0,254-0,625)$ & $<0,001$ \\
\hline Kamrai tachycardia & - & $\mathrm{ns}$ & - & ns \\
\hline Iniciális nem sokkolandó ritmus & $2,416(1,412-4,132)$ & 0,001 & $2,698(1,717-4,241)$ & $<0,001$ \\
\hline Asystolia & - & $\mathrm{ns}$ & $2,131(1,295-3,507)$ & 0,003 \\
\hline Bradycardia & - & ns & - & $\mathrm{ns}$ \\
\hline Pulzus nélküli elektromos aktivitás & $2,765(1,344-5,689)$ & 0,006 & $2,816(1,474-5,380)$ & 0,002 \\
\hline \multicolumn{5}{|l|}{ Katecholaminigény } \\
\hline CPR alatt $(\mathrm{A})$ & - & ns & $2,057(1,243-3,404)$ & 0,005 \\
\hline ITO-n (NA/DA/DB) & $3,079(1,745-5,433)$ & $<0,001$ & $2,445(1,55-3,850)$ & $<0,001$ \\
\hline
\end{tabular}

$\mathrm{A}=$ adrenalin $\mathrm{BKEF}=$ bal kamrai ejekciós frakció $\mathrm{CABG}=$ coronariaartéria-bypassgraft $; \mathrm{CI}=$ konfidenciaintervallum; $\mathrm{CKD}$-EPI $=$ krónikus vesebetegség-epidemiológiai együttmúködés; $\mathrm{CPR}=$ cardiopulmonalis resuscitatio; $\mathrm{DA}=$ dopamin; $\mathrm{DB}=$ dobutamin; $\mathrm{eGFR}=$ becsült glomerulusfiltrációs ráta; $\mathrm{ITO}=$ intenzív terápiás osztály; $\mathrm{mCSRS}$ = módosított cardiogen shock kockázati pontszám; NA = noradrenalin; ns = nem szignifikáns; $\mathrm{OR}=$ odds ratio

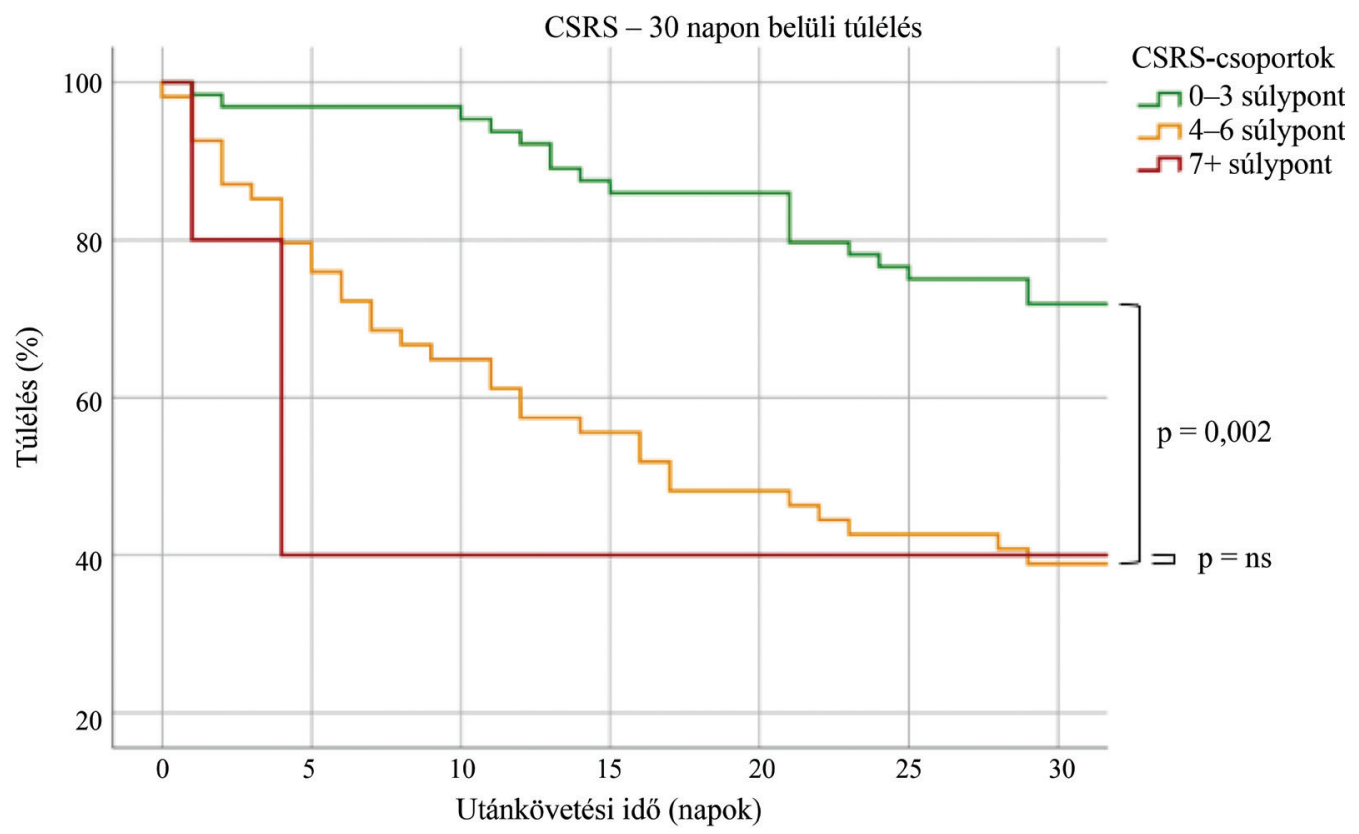

\begin{tabular}{l|l} 
3. ábra & $\begin{array}{l}\text { A CSRS szerinti összevont csoportok túlélési görbéje } \\
\text { CSRS = cardiogen shock kockázati pontszám; ns = nem szignifikáns }\end{array}$
\end{tabular} 


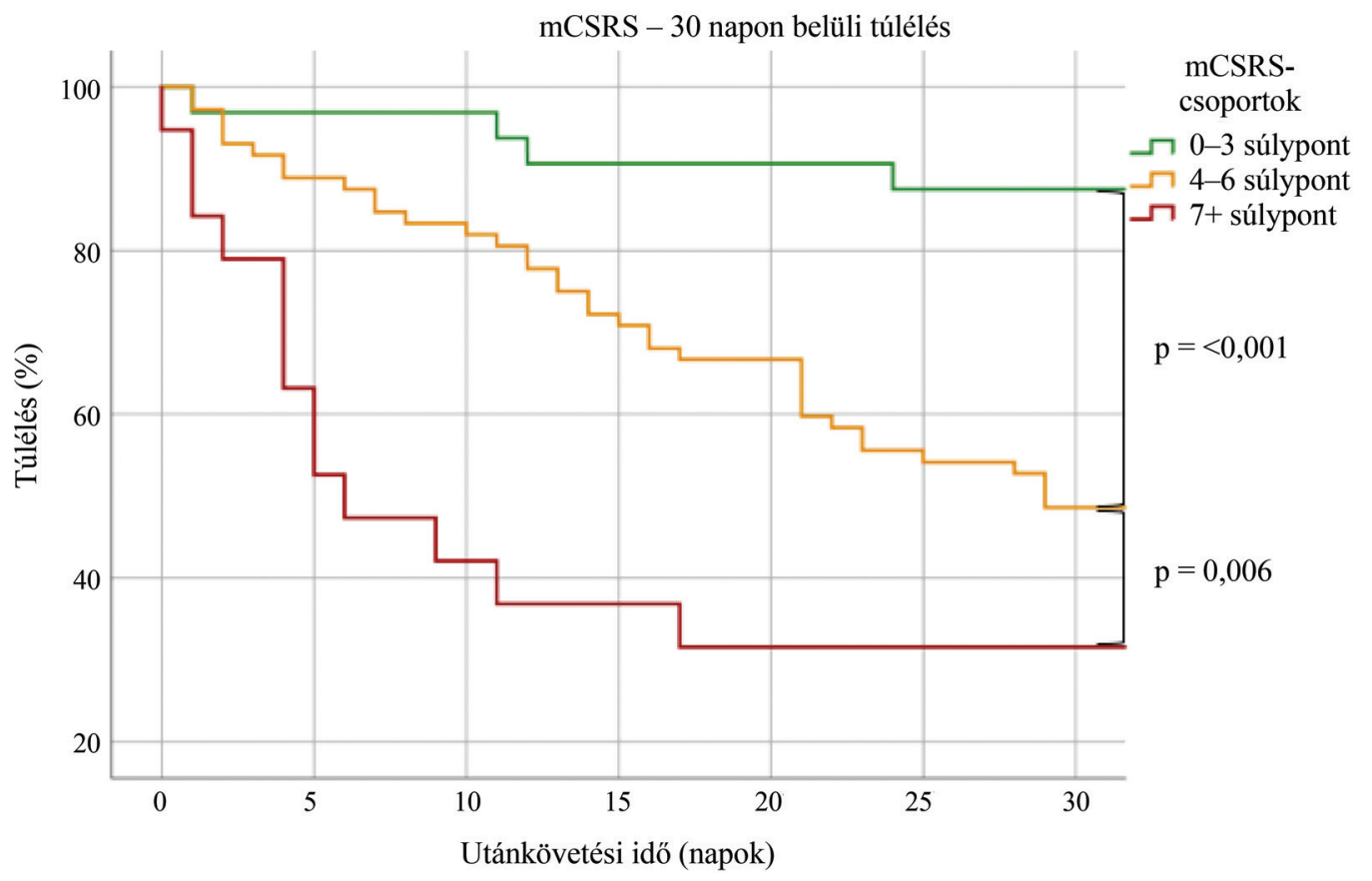

4. ábra

$\mid \begin{aligned} & \text { A mCSRS szerinti összevont csoportok túlélési görbéje } \\ & \text { mCSRS = módosított cardiogen shock kockázati pontszám }\end{aligned}$

Nem találtunk szignifikáns összefüggést sem a korai, sem a késői mortalitás tekintetében az újraélesztett beteg életkorával, a korábban elszenvedett myocardialis infarctussal és az anamnesztikus CABG-mútéttel.

A CSRS- és a mCSRS-pontrendszer szerinti „0-3”, "4-6” és „7 feletti” összesített súlyponttal jellemzett 3 csoportot hoztunk létre (2. ábra). Az összevont csoportok (0-3, 4-6 és 7+ súlypontok szerint) túlélését logrank (Mantel-Cox-) teszttel hasonlítottuk össze. A CSRS alapján az „0-3” és „4-6” ponttal rendelkező csoportok között találtunk szignifikáns statisztikai különbséget $(\mathrm{p}=0,002)$, míg a „4-6” és „7+” csoportok túlélése között nem mutatkozott szignifikáns különbség. A mCSRS alkalmazását követóen mind a „0-3” és „4-6” $(p \leq 0,001)$, mind a „4-6” és ,7+” $(p=0,006)$ csoportok között szignifikáns különbséget találtunk a 30 napos mortalitás tekintetében (3. és 4. ábra).

\section{Megbeszélés}

A vizsgálatunk során egyszerü, korai, a beteg felvételekor regisztrált paraméterekre alapozott és gyorsan használható pontrendszert kerestünk az újraélesztett betegek rövid és hosszú távú mortalitásbecsléséhez. A CSRS és a mCSRS klinikai gyakorlatban történő használatához szükséges, pontrendszerben meghatározott adatok könnyen, a beteg felvételét követő néhány órában rendelkezésünkre állnak az intenzív osztályon, ezért a pontrendszer egyszerűen alkalmazható.

Az újraélesztés helyszíne szerinti megoszlásból kiemelendő, hogy az OHCA-esetek 50\%-ában a keringésmeg- állás a beteg lakásában történik, ahol a túlélést meghatározó lehet a hozzátartozók alapszintû újraélesztési ismerete, illetve - akár a mentőirányító által instruált laikus újraélesztés megkezdése a mentő kiérkezéséig. Az általunk vizsgált hirtelen szívmegállások nemek szerinti megoszlása mutatja a cardiovascularis betegségekre jellemző tendenciát, azonban a vizsgált betegpopulációnkban a férfiak aránya magasabb volt (férfiak : nők - 69 : 31) az ismert irodalmi adatoknál [9].

A hirtelen szívmegállás hátterében álló akut coronaria szindróma előfordulása a vizsgált populáció körében magasabb az irodalmi adatoknál [5]. Ennek oka lehet, hogy az esetek a legtöbbször coronaria- vagy más szív-ér rendszeri betegséggel érkeznek ellátásra a Városmajori Szívés Érgyógyászati Klinikára, így az intenzív terápiás osztályon levő újraélesztett betegpopuláció szelektált.

A mortalitás és a vizsgált pontrendszerek változóinak Cox-regressziós vizsgálata során kiderült, hogy az általunk választott, cardiogen shockra alkalmazott CSRSpontrendszer változóinak nem mindegyike mutat összefüggést sem a korai (30 nap), sem a késői (360 nap) mortalitással. Tanulmányunk egyértelmúen bizonyította, hogy a reanimált beteg korai és késői mortalitását egyértelmúen meghatározza a felvételkori neurológiai állapot, a bal kamrai ejekciós frakció, a szérumlaktát, a vesefunkció, az iniciális ritmus és a katecholaminigény. Nem találtunk egyértelmű összefüggést sem a korai, sem a késői mortalitással az életkor és az anamnesztikus myocardialis infarctus és/vagy CABG esetében sem.

A túlélési görbék és a log-rank tesztek alapján a mCSRS pontosabban definiálja és differenciálja egymás- 
tól az általunk hozzáadott két extra, újraélesztésre specifikus súlyozófaktorral az enyhe, a közepes és a magas mortalitási rizikóval bíró betegpopulációkat, mint a CSRS. A túlélési görbék alapján szembetúnő, hogy az újraélesztést követő rövid időszakban élesen szétválnak az általunk képzett különböző rizikócsoportok túlélési esélyei.

A hozzátartozók és a kollégák számára egy ehhez hasonló, validált, a várható mortalitást előre jelző pontrendszer informatív, de a terápiát negatív irányba nem befolyásoló információt szolgáltathat. Meglátásunk szerint különös körültekintést igényel az intenzív terápiás ellátás során a magas pontszámmal bíró újraélesztett beteg.

A retrospektív tanulmány során a legnagyobb adatvesztést két tényező (a mentésdokumentáció és rutinszerü szérumlaktátszint-mérés hiánya) okozta. A nagy adatvesztés napjainkban már kiküszöbölhető az elektronikus mentésdokumentációval és a rutinszerű szérumlaktátszint-mérésre alkalmas vérgázanalízis-géppel.

\section{Következtetés}

Összegzésként elmondható, hogy az ígéretes első eredmények alapján a továbbiakban mind retrospektív vizsgálatunk kibővítésével, mind egy prospektív vizsgálat indításával azon dolgozunk, hogy új faktorok hozzáadásával saját, validált pontrendszert dolgozzunk ki, mely gyorsan, egyszerüen és az újraélesztést követő intenzív terápiás ellátás első néhány órájában rendelkezésünkre álló adatokból becsülheti meg az újraélesztés utáni mortalitást, illetve a várható, optimális neurológiai kimenetelt nemcsak a kórházon kívüli, hanem a kórházon belüli szívmegállás esetében is.

Regionális Tudományos és Kutatásetikai Bizottság engedélyszáma: $227 / 2018$

(A vizsgálat cime: CardShock és módositott CardShock Risk Score alkalmazhatóságának vizsgálata újraélesztett betegek körében)

Anyagi támogatás: A kutatás és a közlemény megírása anyagi támogatásban nem részesült.

Szerzői munkamegosztás: K. B.: Irodalomkutatás, adatgyưjtés, a kézirat összeállítása, az ábrák és a táblázatok elkészítése. F.-Gy. A., Sz.-T. Zs., Ny. P., P. A., J. Zs., K. E., P. D.: A munkacsoport tagjai. Részt vettek a kézirat szakmai véleményezésében. B. D., M. L., R. Z., D. G., V.-P. H., G. L., M. B.: A klinikai ellátásban tevékenykedtek. Z. E.: Témavezetóként irányította a kutatást, és részt vett a kézirat végső formájának kialakításában. A cikk végleges változatát valamennyi szerző elolvasta és jóváhagyta.

Érdekeltségek: A szerzőknek nincsenek érdekeltségeik.

\section{Irodalom}

[1] Kasper DL, Fauci AS, Hauser SL, et al. Harrison's Principles of Internal Medicine. 19th edn. McGraw-Hill Medical Publ. Division, New York, NY, 2015; pp. 1764-1771.

[2] Priori SG, Blomström-Lundqvist C, Mazzanti A, et al. 2015 ESC guidelines for the management of patients with ventricular arrhythmias and the prevention of sudden cardiac death: the Task Force for the Management of Patients with Ventricular Arrhythmias and the Prevention of Sudden Cardiac Death of the European Society of Cardiology (ESC). Endorsed by: Association for European Paediatric and Congenital Cardiology (AEPC). Eur Heart J. 2015; 36: 2793-2867.

[3] Thomas H, Diamond J, Vieco A, et al. Global atlas of cardiovascular disease 2000-2016: the path to prevention and control. Glob Heart 2018; 13: 143-163.

[4] Siscovick DS, Podrid PJ. Overview of sudden cardiac arrest and sudden cardiac death. UpToDate. Topic 963 Version 10.0.

[5] Zheng ZJ, Croft JB, Giles WH, et al. Sudden cardiac death in the United States, 1989 to 1998 . Circulation 2001; 104: 21582163.

[6] Daya MR, Schmicker RH, Zive DM, et al. Out-of-hospital cardiac arrest survival improving over time: results from the Resuscitation Outcomes Consortium (ROC). Resuscitation 2015; 91: $108-115$.

[7] Atwood C, Eisenberg MS, Herlitz J, et al. Incidence of EMStreated out-of-hospital cardiac arrest in Europe. Resuscitation $2005 ; 67: 75-80$.

[8] Gräsner JT, Lefering R, Koster RW, et al. EuReCa ONE-27 Nations, ONE Europe, ONE Registry: a prospective one month analysis of out-of-hospital cardiac arrest outcomes in 27 countries in Europe. Resuscitation 2016; 105: 188-195. [Erratum: Resuscitation 2016; 109: 145-146.]

[9] Chugh SS, Jui J, Gunson K, et al. Current burden of sudden cardiac death: multiple source surveillance versus retrospective death certificate-based review in a large U.S. community. J Am Coll Cardiol. 2004; 44: 1268-1275.

[10] Gőbl G, Gáspár T, Nagy J, et al. National resuscitation database: out of hospital resuscitations between 2003 and 2005. [Nemzeti reszuszcitációs adatbázis: kórházon kívüli esetek 2003-2005.] Újraélesztés 2006; 4: 20-28. [Hungarian]

[11] Góbl G, Gáspár T. Out-of-hospital cardiac arrest in Hungary: the Utstein database [Conference abstract]. Resuscitation 2006; 70: 308.

[12] Lloyd-Jones DM, Wilson PW, Larson MG, et al. Framingham risk score and prediction of lifetime risk for coronary heart disease. Am J Cardiol. 2004; 94: 20-24.

[13] Myerburg RJ, Kessler KM, Castellanos A. Sudden cardiac death. Structure, function, and time-dependence of risk. Circulation 1992; 85( 1 Suppl): I2-10.

[14] Monsieurs KG, Nolan JP, Bossaert LL, et al. European Resuscitation Council Guidelines for Resuscitation 2015: Section 1. Executive summary. Resuscitation 2015; 95: 1-80.

[15] Nolan JP, Neumar RW, Adrie C, et al. Post-cardiac arrest syndrome: epidemiology, pathophysiology, treatment, and prognostication. Resuscitation 2008; 79: 350-379.

[16] Nolan JP, Soar J, Cariou A, et al. European Resuscitation Council and European Society of Intensive Care Medicine Guidelines for Post-resuscitation Care 2015: Section 5 of the European Resuscitation Council Guidelines for Resuscitation 2015. Resuscitation 2015; 95: 202-222.

[17] Spaite DW, Bobrow BJ, Stolz U, et al. Statewide regionalization of postarrest care for out-of-hospital cardiac arrest: association with survival and neurologic outcome. Ann Emerg Med. 2014; 64: 496-506.el.

[18] Søholm H, Wachtell K, Nielsen SL, et al. Tertiary centres have improved survival compared to other hospitals in the Copenha- 
gen area after out-of-hospital cardiac arrest. Resuscitation 2013; 84: 162-167.

[19] Zima E. Target temperature in post-cardiac-arrest complex intensive care. Arguments for mild therapeutic hypothermic treatment. [Célhőmérséklet a tartós újraélesztés utáni komplex intenzív kezelés során. Állásfoglalás az enyhe terápiás hypothermia mellett.] Orv Hetil. 2019; 160: 1840-1844. [Hungarian]

[20] Maupain C, Bougouin W, Lamhaut L, et al. The CAHP (Cardiac Arrest Hospital Prognosis) score: a tool for risk stratification after out-of-hospital cardiac arrest. Eur Heart J. 2015; 37: 3222 3228.

[21] Le Gall JR, Lemeshow S, Saulnier F. A new simplified acute physiology score (SAPS II) based on a European/North American multicenter study. JAMA 1993; 270: 2957-2963.

[22] Knaus WA, Draper EA, Wagner DP, et al. APACHE II: a severity of disease classification system. Crit Care Med. 1985; 13: 818829.

[23] Harjola VP, Lassus J, Sionis A, et al. Clinical picture and risk prediction of short-term mortality in cardiogenic shock. Eur J Heart Fail. 2015; 17: 501-509.

[24] Samuels LE, Kaufman MS, Thomas MP, et al. Pharmacological criteria for ventricular assist device insertion following postcardiotomy shock: experience with the Abiomed BVS system. J Card Surg. 1999; 14: 288-293.

[25] Pap Zs, Fekete-Gyór A. Multiorgan dysfunction in PCAS patients depending on catecholamine drug requirements. [PCAS betegek többszervi diszfunkciója a katekolamin gyógyszerigény függvényében.] Orvosképzés 2017; 92: 171. [Hungarian]
[26] Hagihara A, Hasegawa M, Abe T, et al. Prehospital epinephrine use and survival among patients with out-of-hospital cardiac arrest. JAMA 2012; 307: 1161-1168.

[27] Olasveengen TM, Wik L, Sunde K, et al. Outcome when adrenaline (epinephrine) was actually given vs. not given - post hoc analysis of a randomized clinical trial. Resuscitation 2012; 83: 327-332.

[28] Andrew E, Nehme Z, Lijovic M, et al. Outcomes following outof-hospital cardiac arrest with an initial cardiac rhythm of asystole or pulseless electrical activity in Victoria, Australia. Resuscitation 2014; 85: 1633-1639.

[29] Vancini-Campanharo CR, Vancini RL, de Lira CA, et al. Cohort study on the factors associated with survival post-cardiac arrest. Sao Paulo Med J. 2015; 133: 495-501.

[30] Bougouin W, Mustafic H, Marijon E, et al. Gender and survival after sudden cardiac arrest: a systematic review and meta-analysis. Resuscitation 2015; 94: 55-60.

[31] Szigethi T, Pileczky D, Pap Zs, et al. Relationship between survival and initial rhythm after cardiac arrest. [Hosszú távú túlélés és iniciális ritmus közötti összefüggés hirtelen szívhalál esetén.] Cardiol Hung. 2017; 47: 30-33. [Hungarian]

(Zima Endre dr., Budapest, Városmajor u. 68., 1122 e-mail: zima.endre@gmail.com)

\section{Az Orvosi Hetilap 2020; 161: 2095. oldalán (49. szám) OH-Kvízre} két helyes megfejtés érkezett.

A beküldők: Dr. Bíró László (Budapest) és Dr. Kónya Csaba (Budapest).

A nyerteseknek szívböl gratulálunk.

Nyereményüket - egy, az Akadémiai Kiadó webáruházában kedvezményes vásárlásra jogosító kupont - e-mailen küldjük el.

A cikk a Creative Commons Attribution 4.0 International License (https://creativecommons.org/licenses/by/4.0/) feltételei szerint publikált Open Access közlemény, melynek szellemében a cikk bármilyen médiumban szabadon felhasználható, megosztható és újraközölhető, feltéve, hogy az eredeti szerző és a közlés helye, illetve a CC License linkje és az esetlegesen végrehajtott módosítások feltüntetésre kerülnek. (SID_1) 